\title{
MI KERING WALUH (Cucurbita moschata) DENGAN ANTIOKSIDAN DAN PEWARNA ALAMI
}

\section{DRY NOODLE PUMPKIN (Cucurbita Moschata) WITH ANTIOXIDANT AND NATURAL DYE}

\author{
Choiroel Anam dan Sri Handajani
}

\begin{abstract}
ABSTRAK
Mie merupakan salah satu jenis makanan yang paling populer di masyarakat. Saat ini mie menjadi kebutuhan masyarakat luas sebagai bahan yang dapat menggantikan makanan pokok. Mie kering adalah mie segar yang telah dikeringkan hingga kadar airnya mencapai 8-10\%. Bahan baku yang digunakan dalam pembuatan mie kering adalah tepung terigu yang selama ini masih impor. Sehingga perlu adanya pengurangan konsumsi tepung terigu dalam pembuatan mie kering. Hal ini bisa disubstitusi dengan labu kuning. Labu kuning adalah tanaman lokal yang melimpah keberadaannya. Angkak merupakan beras yang telah difermentasi dengan Monascus sp yang mengandung antosianin (pembentuk warna merah) yang bisa digunakan sebagai pewarna alami.

Oleh karena itu perlu adanya penelitian guna mengetahui prosentase tepung terigu, labu kuning dan tepung angkak yang tepat dalam pembuatan mie kering yang bisa diterima oleh konsumen. Juga untuk mengetahui pengaruh penambahan labu kuning dan tepung angkak terhadap kandungan kadar air, abu dan protein, serta pengaruh terhadap kesukaan panelis terhadap parameter warna, aroma, elastisitas, rasa dan keseluruhan.

Penelitian ini menggunakan Rancangan Acak Lengkap faktorial dengan dua faktor, faktor pertama yaitu substitusi labu kuning $(0 \%, 20 \%, 30 \%, 40 \%)$ terhadap tepung terigu dan faktor kedua yaitu penambahan tepung angkak $(0 \%, 1 \%, 2 \%, 3 \%)$. Hasil penelitian menunjukkan prosentase penggunaan labu kuning yang paling disukai oleh panelis yaitu mie kering dengan kombinasi perlakuan substitusi labu kuning sebesar $20 \%$ dengan tanpa penambahan tepung angkak. Semakin besar substitusi labu kuning akan meningkatkan kadar abu, sedangkan kadar air, kadar protein dan aktivitas antioksidan akan menurun secara tidak berbeda nyata. Semakin besar penambahan tepung angkak akan meningkatkan kadar abu, kadar protein dan aktivitas antioksidan, sedangkan kadar air menurun. Warna, aroma dan rasa mie kering cenderung tidak berpengaruh terhadap perlakuan substitusi labu kuning dan penambahan tepung angkak. Semakin banyak substitusi labu kuning, maka penilaian panelis terhadap parameter elastisitas akan semakin menurun secara tidak berbeda nyata. Semakin banyak penambahan tepung angkak, akan menurunkan penilaian panelis terhadap parameter elastisitas. Parameter keseluruhan cenderung tidak berpengaruh terhadap perlakuan substitusi labu kuning dan penambahan tepung angkak. Sampel dengan nilai tertinggi yaitu perlakuan substitusi labu kuning 20\% tanpa penambahan tepung angkak.
\end{abstract}

Kata kunci : waluh, tepung angkak, mie kering

\section{ABSTRACT}

Noodle is kind of most popular food. Dry noodle is raw noodle that dry till 8 - $10 \%$ moisture contents. It's raw material is wealth flour that imported. So that it is necessary to reduce wealth flour consumption in dry noodle production. It can substitute by yellow pumpkin. Yellow pumpkin is local plant that a lot. Angkak is fermented rice by Monascus sp that contain antosianin (red color agent) can use as natural colorant. So that, its need study to define exactly the percentage of wealth flour, yellow pumpkin and angkak flour in dry noodle production that accept by consumer. It is also to know the effect of yellow pumpkin and angkak addition on antioxidant activity and nutrient content (moisture, ash and protein content), also the effect on sensory character (color, aroma, elasticity, taste and overall).

This study use factorial completely random design with two factors, first factor is the yellow pumpkin substitute $(0 \%, 20 \%, 30 \%$ and $40 \%)$ on wealth flour and second factor is the angkak flour addition $(0 \%, 1 \%, 2 \%$ and $3 \%)$. The result of this study shown the most prefer yellow pumpkin percentage use by the 
panelist is dry noodle with $20 \%$ substitute treat combine without angkak flour addition. As bigger as yellow pumpkin substitute will increase the moisture and ash content, then protein content and antioxidant activity insignificantly decrease. As bigger as angkak flour addition will increase the ash, protein content and antioxidant activity, then moisture content decrease. The dry noodle's aroma and taste was unaffected by the yellow pumpkin substitute and angkak addition. As bigger as angkak flour addition, will decrease the elasticity score by the panelist. Overall parameter, was almost unaffected by the yellow pumpkin substitute and angkak addition. The highest score is dry noodle with $20 \%$ yellow pumpkin substitute treat without angkak flour addition.

Keywords: yellow pumpkin, angkak flour, dry noodle.

\section{PENDAHULUAN}

Kecenderungan dan pola hidup masyarakat modern yang menuntut makanan siap saji akibat aktivitas yang padat, mie telah digunakan sebagai salah satu pangan pengganti nasi. Hal ini tentu sangat menguntungkan ditinjau dari sudut pandang penganekaragaman konsumsi pangan agar masyarakat kita tidak terlalu bergantung kepada beras sebagai makanan pokok. Mie mempunyai banyak keunggulan dan disukai banyak masyarakat Indonesia dalam hal tekstur, rasa, kenampakan, dan kepraktisan penggunaannya.

Bahan baku mie berasal dari tepung terigu yang sampai saat ini masih harus diimpor dari negara lain, Berdasarkan data BPS (2007), pada tahun 2003 impor terigu mencapai 343.144,9 ton sedangkan tahun 2006 mencapai 536.961,6 ton meningkat $19 \%$. Harga tepung terigu dari Rp. 3.613 per kg pada November 2007 naik menjadi Rp. 6.134 per $\mathrm{kg}$ pada Desember 2007 (Departemen Perdagangan, 2008) dan pada Januari 2008 mencapai Rp. 13.000 sampai Rp. 13.400 per $\mathrm{kg}$. Hal ini sangat merugikan masyarakat indonesia, sehingga perlu dilakukan penelitian untuk mencari bahan pengganti tepung terigu tersebut.

Waluh (Curcurbita Moschata, ex poir) atau sering disebut labu kuning menjadi salah satu bahan alternatif untuk substitusi tepung terigu karena dapat menggantikan sumber karbohidrat yang ada pada tepung terigu. Pertimbangan pemanfaatan buah waluh dalam pembuatan mie kering selain karena waluh banyak mengandung karbohidrat, vitamin, dan serat, juga sebagai salah satu altenatif dari usaha penganekaragaman hasil waluh dan untuk meningkatkan nilai ekonomisnya. Buah waluh dapat diolah menjadi bermacammacam produk olahan makanan yang menyehatkan tubuh (sebagai pangan fungsional). Mengingat kandungan karbohidrat yang tinggi, kaya vitamin (A dan C) dan mineral (Ca, Fe, dan Na). Sekitar
100 gram waluh mengandung vitamin A 29.030 IU, vitamin C $23 \mathrm{mg}$, magnesium $66 \mathrm{mg}$, kalsium $113 \mathrm{mg}$, fosfor $118 \mathrm{mg}$, zat besi $1.8 \mathrm{mg}$, sodium 9 $\mathrm{mg}$ dan potasium $1.089 \mathrm{mg}$. Waluh juga mengandung inulin dan serat pangan yang sangat dibutuhkan untuk pemeliharaan kesehatan. Selain itu, waluh merupakan salah satu jenis buah yang mengandung karotenoid tinggi. Itulah sebabnya mendapat julukan "raja betakaroten". Betakaroten berfungsi melindungi mata dari serangan katarak. Betakaroten dalam waluh juga berperan untuk melindungi diri dari serangan kanker, jantung, diabetes melitus, aneka kanker, proses penuaan dini, dan gangguan respon imun. Betakaroten merupakan salah satu senyawa karotenoid yang mempunyai aktivitas vitamin A sangat tinggi. Dalam saluran pencernaan, betakaroten dikonversi oleh sistem enzim menjadi retinol, yang selanjutnya berfungsi sebagai vitamin A. Betakaroten dan karotenoid lain yang tidak terkonversi menjadi vitamin A, mempunyai sifat antioksidan, sehingga dapat menjaga integritas sel tubuh.

Angkak atau beras merah adalah produk fermentasi menggunakan kapang Manascus sp. Dalam teks tradisional The Ancient Chinese Pharmacopoeia disebutkan bahwa angkak digunakan sebagai obat untuk melancarkan pencernaan dan sirkulasi darah. Beberapa spesies kapang telah digunakan untuk memproduksi angkak, diantaranya adalah Monascus purpureus, M. pilosus, dan M. anka. Negara-negara Taiwan, Jepang, Korea, dan Hongkong memproduksi angkak untuk keperluan sebagai pewarna alami makanan. Berdasar uraian diatas, maka perlu dilakukan penelitian mengenai penggunaan waluh dalam pembuatan mi kering untuk substitusi tepung terigu yang sekaligus sebagai antioksidan dan pewarna alami angkak sebagai pengganti pewarna sintetis yang dapat menyebabkan karsinogenik dalam tubuh. 


\section{METODE PENELITIAN}

\section{Bahan dan Alat}

Bahan

Bahan yang digunakan adalah buah waluh bokor, tepung angkak, tepung terigu jenis hard, aquades $\left(\mathrm{H}_{2} \mathrm{O}\right)$, garam $(\mathrm{NaCl})$, soda abu atau natrium karbonat $\left(\mathrm{Na}_{2} \mathrm{CO}_{3}\right)$ dan kalium karbonat $\left(\mathrm{K}_{2} \mathrm{CO}_{3}\right)$ 1:1 teknis. Sedangkan untuk analisa proksimat berupa $\mathrm{H}_{2} \mathrm{SO}_{4}, \mathrm{HgO}, \mathrm{NaOH}, \mathrm{Na}_{2} \mathrm{~S}_{2} \mathrm{O}_{3}$, $\mathrm{K}_{2} \mathrm{SO}_{4}$, larutan asam borat jenuh $\left(\mathrm{Na}_{2} \mathrm{~B}_{4} \mathrm{O}_{7} 10 \mathrm{H}_{2} \mathrm{O}\right)$ dan $\mathrm{HCl}$ 0,02 $\mathrm{N}$ dan petrolium ether.

Alat

Alat yang digunakan yaitu alat pencetak mie, baskom plastik, kompor gas, wajan, bin dryer,

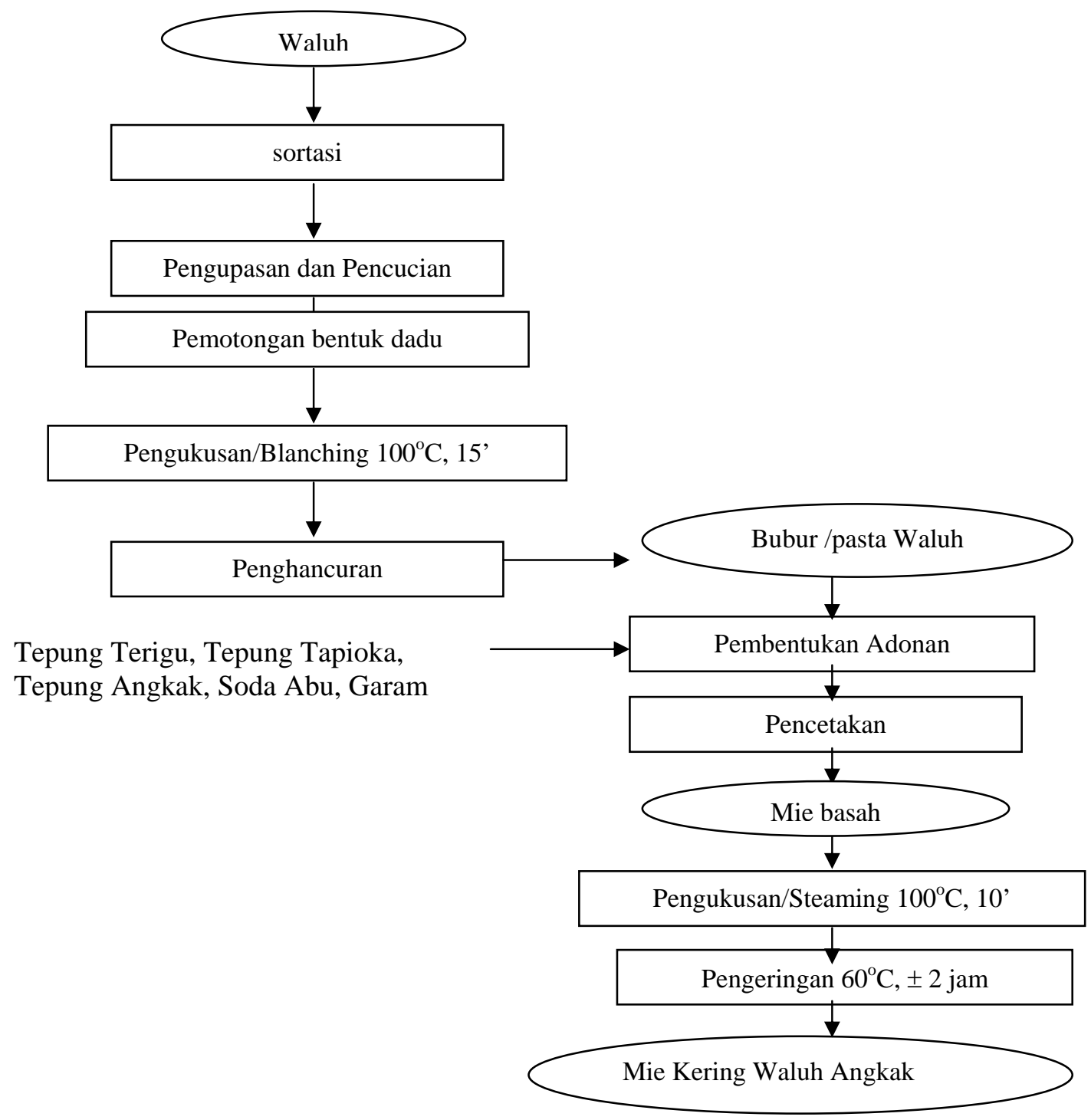

Gambar 1. Diagram Alir Proses Pembuatan Mie Waluh Angkak cabinet dryer, blender dan peralatan untuk uji sensoris. Selain itu juga peralatan untuk analisa proksimat (kadar air, kadar abu, kadar protein dan karbohidrat) serta aktivitas antioksidan.

\section{Perancangan Penelitian}

Penelitian ini menggunakan percobaan rancangan faktorial dengan dua faktor perlakuan yaitu substitusi pasta waluh dan konsentrasi angkak. Substitusi waluh yang digunakan yaitu $0 \%$, $20 \%$, 30\%, dan $40 \%$. Sedang penambahan tepung angkak yaitu $0 \%, 1 \%, 2 \%$ dan $3 \%$.

Mie kering yang dihasilkan kemudian dianalisa kandungan air, abu dan protein, karbohidrat, lemak, aktivitas antioksidan dan uji sensoris. 
Tabel.1. Hasil uji kadar air mie kering

\begin{tabular}{ccccc}
\hline Pasta Waluh & $0 \%$ & $20 \%$ & $30 \%$ & $40 \%$ \\
\hline Angkak & & & & \\
$1 \%$ & $11.8953^{\mathrm{i}}$ & $8.7588^{\mathrm{a}}$ & $10.6558^{\mathrm{h}}$ & $9.9731^{\mathrm{f}}$ \\
$2 \%$ & $10.4563^{\mathrm{g}}$ & $9.5200^{\mathrm{de}}$ & $9.3287^{\mathrm{cd}}$ & $9.5559^{\mathrm{e}}$ \\
$3 \%$ & $12.7419^{\mathrm{j}}$ & $9.0338^{\mathrm{b}}$ & $9.3166^{\mathrm{cd}}$ & $8.7966^{\mathrm{a}}$ \\
\hline
\end{tabular}

Huruf yang sama dibelakang angka menyatakan tidak berbeda nyata pada taraf $5 \%$

Tabel. 2. Hasil uji kadar abu mie kering

\begin{tabular}{|c|c|c|c|c|}
\hline $\begin{array}{c}\text { Pasta Waltuht } \\
\text { Angkak }\end{array}$ & $0 \%$ & $20 \%$ & $30 \%$ & $40 \%$ \\
\hline $0 \%$ & $1.3636^{\mathrm{ab}}$ & $1.2692^{\mathrm{a}}$ & $1.4008^{\mathrm{abc}}$ & $1.4204^{\mathrm{abcd}}$ \\
\hline $1 \%$ & $1.4818^{\text {abcde }}$ & $1.5552^{\text {abcde }}$ & 1.6381 bcde & $1.5424^{\text {abcde }}$ \\
\hline $2 \%$ & $1.7342^{\text {cdef }}$ & $1.7611^{\text {def }}$ & $1.8049^{\text {ef }}$ & $1.2958^{\mathrm{ab}}$ \\
\hline $3 \%$ & $1.8100^{\text {ef }}$ & $2.0010^{f}$ & $1.7466^{\text {cdef }}$ & 1.5760 abcde \\
\hline
\end{tabular}

Huruf yang sama dibelakang angka menyatakan tidak berbeda nyata pada taraf $5 \%$

Tabel. 3. Hasil uji kadar protein mie kering

\begin{tabular}{ccccc}
\hline Pasta Waluh & $0 \%$ & $20 \%$ & $30 \%$ & $40 \%$ \\
\hline Angkak & & & & \\
$1 \%$ & $13.3640^{\text {bcd }}$ & $10.7730^{\mathrm{a}}$ & $11.9700^{\mathrm{ab}}$ & $11.9700^{\mathrm{ab}}$ \\
$2 \%$ & $13.9650^{\text {bcd }}$ & $13.1670^{\mathrm{bcd}}$ & $12.3690^{\mathrm{abc}}$ & $11.9700^{\mathrm{ab}}$ \\
$3 \%$ & $13.9650^{\text {bcd }}$ & $10.3740^{\mathrm{a}}$ & $13.9650^{\mathrm{bcd}}$ & $10.3740^{\mathrm{a}}$ \\
\hline
\end{tabular}

Huruf yang sama dibelakang angka menyatakan tidak berbeda nyata pada taraf $5 \%$

Tabel. 4. Hasil uji aktivitas antioksidan mie kering

\begin{tabular}{ccccc}
\hline Perlakuan & $0 \%$ & $20 \%$ & $30 \%$ & $40 \%$ \\
\hline $0 \%$ & 18,3077 & 19,2308 & 17,4615 & 19,4615 \\
$1 \%$ & 20,3846 & 21,3077 & 21,2615 & 19,8507 \\
$2 \%$ & 21,9231 & 22,3851 & 22,3077 & 21,1538 \\
$3 \%$ & 26,9231 & 25,9229 & 24,5384 & 22,6154 \\
\hline
\end{tabular}

Huruf yang sama dibelakang angka menyatakan tidak berbeda nyata pada

\section{HASIL DAN PEMBAHASAN}

\section{Kadar air mie kering}

Air merupakan komponen penting dalam bahan makanan karena dapat mempengaruhi kenampakan, tekstur serta cita rasa makanan (Slamet Sudarmadji dkk, 2003). Pengujian kadar air mie kering dapat dilihat pada tabel 1 . Berdasarkan tabel 1 interaksi antar perlakuan substitusi pasta waluh berbagai konsentrasi dengan tanpa penambahan tepung angkak menunjukkan adanya beda nyata pada tiap konsentrasi pasta waluh yang ditambahkan. Sampel mie kering kontrol memiliki kadar air yang paling tinggi, hal ini disebabkan karena pada sampel tersebut hanya terdapat tepung terigu saja, sehingga kadar gluten dalam sampel mie kering cukup tinggi. Gluten yang tinggi mengakibatkan daya ikat air pada mie kering menjadi tinggi pula, karena gluten terjadi karena pencampuran tepung terigu dengan air.

Nilai sampel mie kering pada interaksi perlakuan penambahan tepung angkak sebesar 1\% terhadap variasi konsentrasi substitusi pasta waluh berbagai konsentrasi terjadi penurunan kadar air pada mie kering. Substitusi tepung terigu 0\% memiliki kadar air yang paling tinggi, yaitu sebesar 10.4563 yang berbeda nyata dengan sampel mie kering yang lain. Hal ini dipengaruhi akan banyaknya kandungan tepung terigu pada sampel tersebut sehingga juga kaya kandungan gluten. Secara umum sampel mie kering yang dihasilkan sudah sesuai dengan SNI mie kering yaitu maksimal $10-11 \%$. 


\section{Kadar Abu Mie Kering}

Abu adalah zat anorganik sisa hasil pembakaran suatu bahan organik. Berdasarkan pengujian kadar abu mie kering didapatkan seperti dalam tabel 2. Berdasarkan tabel tersebut di atas, interaksi antara sampel satu dengan yang lain mempunyai nilai tidak beda nyata. Kadar abu sampel mie kering berkisar antara 1,2692 $2,0010 \%$. Substitusi pasta waluh dan penambahan angkak tidak mempengaruhi kadar abu secara nyata, dimana hal ini sudah sesuai dengan standar SNI, yaitu kadar abu untuk mie kering berkisar antara $1-2 \%$.

\section{Kadar Protein Mie Kering}

Protein merupakan zat makanan yang amat penting bagi tubuh karena zat ini selain berfungsi sebagai bahan bakar dalam tubuh juga berfungsi sebagai zat pembangun dan pengatur (Winarno, 1991). Berdasarkan pengujian kadar protein mie kering didapatkan hasil seperti pada tabel 3 . Berdasarkan hasil uji kadar protein yang terdapat pada tabel 3 di atas, diketahui bahwa sampel kontrol berbeda nyata dengan sampel substitusi pasta waluh 20\%, 30\% dam 40\%. Hal ini dipengaruhi besarnya jumlah tepung terigu yang digunakan dalam pembuatan mie kering, sehingga nilai kadar protein mie kering tanpa substitusi lebih tinggi dibandingkan dengan sampel yang lain. Pada penambahan tepung angkak sebesar 1\%, tidak berbeda nyata dengan sampel yang lain. Penambahan angkak dapat meningkatkan kadar protein hal ini diduga penambahan peningkatan protein berasal dari sel Manascus sp.

\section{Aktivitas Antioksidan Mie Kering}

Antioksidan adalah senyawa yang melindungi senyawa atau jaringan dari efek destruktif jaringan oksigen (Swarth, 2004). Menurut Kumalaningsih (2006) asupan makanan yang banyak mengandung vitamin $\mathrm{C}, \mathrm{E}$, dan betakaroten serta senyawa fenolik dan flavonoid dapat melindungi kita dari serangan radikal bebas karena senyawa ini bersifat sebagai antioksidan alami. Berdasarkan pengujian aktivitas antoiksidan mie kering didapatkan hasil seperti pada tabel 4.Berdasarkan hasil pada table 4 di atas, sampel mie kering kontrol memiliki nilai aktivitas antioksidan yang cukup tinggi, yaitu sebesar 26,9231\%. Penambahan angkak menunjukkan dapat meningkatkan aktivitas antioksidan mie kering. Sedangkan substitusi waluh meskipun mempunyai kecenderungan meningkatkan anktivitas antioksidan namun pada beberapa sampel menunjukkan penurunan. Hal ini duduga karena sebagian sebar sumber antioksidan pada waluh merupakan vitamin $\mathrm{C}$ dan betakaroten yang akan tidak tahan panas pada proses pembuatan mie kering.

\section{Uji Sensoris Mie Kering}

\section{Warna Mie Kering}

Warna menjadi salah satu parameter yang sangat menentukan kesukaan konsumen terhadap suatu produk. Warna yang menarik bias menimbulkan rasa suka terlebih dahulu sebelum konsumen tersebut mengkonsumsi makanan tersebut. Angkak merupakan salah satu produk fermentasi beras dengan menggunakan kapang Monascus sp. yang biasa digunakan sebagai pewarna alami merah untuk makanan serta obat untuk melancarkan pencernaan dan sirkulasi darah (Ardiansyah, 2005). Penambahan angkak pada pembuatan mie kering ini diharapkan bisa menambah kesukaan konsumen terhadap mie kering yang dihasilkan. Suatu bahan yang dinilai bergizi, enak, dan teksturnya sangat baik tidak akan dimakan apabila memiliki warna yang tidak sedap dipandang atau memberi kesan telah menyimpang dari warna yang seharusnya. Penerimaan warna suatu bahan berbeda-beda tergantung faktor alam, geografis, dan aspek sosial masyarakat penerima (Winarno, 2002). Warna bukan merupakan suatu zat/benda melainkan suatu sensasi seseorang oleh karena adanya rangsangan dari seberkas energi radiasi yang jatuh ke indera mata/retina mata (Kartika et al, 1988).

Hasil uji sensoris pada atribut warna, secara umum panelis memberikan penilaian warna mie kering yaitu pada kisaran agak tidak suka sampai suka $(4,32-7,08)$. Hal ini dikarenakan adanya warna merah muda pada sampel mie kering, sehingga panelis lebih menyukai dibandingkan dengan mie kering tanpa penambahan tepung angkak (kontrol). Penambahan tepung angkak yang berlebih pada sampel mengakibatkan penilaian panelis terhadap sampel menjadi berkurang.. Hal ini dikarenakan adanya warna kuning dari waluh dan mreah pada angkak mengakibatkan warna agak sedikit gelap, sehingga kurang disukai panelis. 


\section{Aroma Mie Kering}

Di dalam industri pangan pengujian terhadap bau dianggap penting karena dengan cepat dapat memberikan hasil penilaian terhadap produk tentang diterima atau tidaknya produk tersebut (Kartika et al, 1988). produk yang memiliki aroma kurang menarik, bisa mengurangi penilaian dan juga minat dari konsumen untuk mengkonsumsinya. Berdasarkan hasil uji sensoris terhadap atribut aroma mie kering, secara umum panelis memberikan nilai netral pada mie kering sampel yaitu dengan rata-rata penilaian 5,28 - 5,96. Artinya aroma dari sampel mie kering dinilai normal sebagai aroma mie kering yang khas. Adanya substitusi pasta waluh dan penambahan tepung angkak ternyata tidak berpengaruh terhadap perubahan aroma pada sampel mie kering. Berarti substitusi pasta waluh dan penambahan tepung angkak baik sebagai pengembangan produk mie dari segi aroma, karena walaupun ditambahkan waluh dan tepung angkak tetap tidak mempengaruhi aroma mie kering tersebut.

\section{Elastisitas Mie Kering}

Berdasarkan hasil uji sensoris mie kering terhadap atribut elastisitas, secara umun penelis memberikan penilaian tidak suka hingga netral, yaitu antara nilai 3,96 - 5,88. Untuk mie kering kontrol panelis memberikan nilai kesukaan netral sebesar 5,88. Hal ini disebabkan karena adanya penambahan pada tepung angkak sebesar 3\% yang menjadikan elastisitas berkurang dan juga dipengaruhi adanya substitusi pasta waluh pada pembuatan sampel mie kering ini sehingga kadar gluten yang ada pada terigu semakin berkurang dengan berkurangnya jumlah tepung terigu yang telah disubstitusi tersebut. Menurut Astawan (1999), tepung terigu memiliki kemampuan untuk membentuk gluten pada saat terigu dibasahi dengan air. Sifat elastis gluten pada adonan mie menyebabkan mie yang dihasilkan tidak mudah putus pada proses pencetakan dan pemasakan. Jika penggunaan terigu tersebut dikurangi dan diganti dengan penambahan ubi jalar kukus maka mengakibatkan mie yang dihasilkan mudah putus dan menurunkan penilaian panelis terhadap elastisitas.

\section{Rasa Mie Kering}

Rasa suatu produk menjadi satu parameter yang tidak bisa dikesampingkan. Pada dasarnya manusia menginginkan pangan yang tentunya enak rasanya selain untuk memenuhi kebutuhan akan kenyang dan kesehatan. Berdasarkan uji sensoris yang dilakukan pada sampel mie kering dengan atribut rasa, secara umum panelis memberikan penilaian rasa yang netral pada sampel mie kering yang disajikan. Penilaian berkisar antara 4,92 5 ,92. Untuk sampel mie kering kotrol panelis memberikan nilai sebesar 5,32. Pada penelitian ini, panelis diberikan sampel mie kering yang telah diseduh tanpa ada bumbu atau perasa apapun.

Rasa mie kering untuk sampel kontrol tidak memiliki beda nyata dengan sampel yang lain. Dengan adanya substitusi pasta waluh tidak berbeda nyata pada setiap perlakuan demikian juga dengan penambahan tepung angkak sesuai dengan konsentrasi masing-masing. Hal ini membuktikan bahwa adanya substitusi tepung terigu dengan menggunakan pasta waluh tidak mempengaruhi rasa pada sampel mie kering yang dihasilkan. Artinya waluh bisa digunakan sebagai alternatif dalam substitusi tepung terigu dengan tidak mempengaruhi rasa dari mie itu sendiri, sehingga konsumen bisa tetap menikmati mie dengan rasa yang khas dan produsen bisa menghemat penggunaan tepung terigu dengan adanya substitusi tersebut.

\section{Keseluruhan Mie Kering}

Penilaian keseluruhan yaitu nilai yang diberikan dari panelis terhadap sampel mie kering yang diuji berdasarkan seluruh parameter yang ada sebelumnya, seperti warna, aroma, tekstur dan rasa. Penilaian keseluruhan dapat mengetahui sampel mana yang disukai oleh panelis dan yang nantinya dipakai sebagai acuan untuk memilih formulasi yang paling disukai panelis. Berdasarkan pengujian yang telah dilakukan, secara keseluruhan panelis memberikan nilai bervariasi, yaitu berkisar antara netral sampai suka $(5,08$ - 6,24). kemungkinan factor dominant penerimaan secara keseluruhan mie kering dipengaruhi dari atribut warna, dimana warna sampel mie kering pada sampel yang berwarna muda atau cerah lebih bagus dan menarik perhatian dari panelis

\section{KESIMPULAN}

Berdasarkan hasil penelitian diatas maka dapat disimpulkan bahwa:

1. Dilihat dari kandungan gizinya secara umum sampel mie kering yang dihasilkan sudah sesuai dengan SNI mie kering.

2. Berdasarkan hasil uji sensoris pada atribut warna dan aroma, secara umum panelis 
memberikan penilaian warna mie kering pada kisaran agak tidak suka sampai suka. Sedangkan rasa mie yang dihasilkan antar perlakuan tidak berbeda nyata Hal ini membuktikan bahwa adanya substitusi tepung terigu dengan menggunakan pasta waluh tidak mempengaruhi rasa pada sampel mie kering yang dihasilkan. Artinya waluh bisa digunakan sebagai alternatif dalam substitusi tepung terigu dengan tidak mempengaruhi rasa dari mie itu sendiri, sehingga konsumen bisa tetap menikmati mie dengan rasa yang khas dan produsen bisa menghemat penggunaan tepung terigu.

3. Elastisitas mie dengan semakin banyak penambahan konsentrasi tepung angkak, maka penilaian panelis semakin berkurang, walaupun penurunan nilai elastisitas disini tidak berbeda nyata dan secara keseluruhan panelis memberikan nilai bervariasi, yaitu berkisar antara agark suka sampai suka

\section{DAFTAR PUSTAKA}

Anonim, 2008. http//:www.Labu Kuning, Mencegah Serangan Jantung Blog Archive $\sim$ Info Boga (Asia Blogging Network).htm. Diakses 24 Desember 2008. 14:32 WIB

Astawan, Made. 1999. Membuat mie dan Bihun. Penebar Swadaya. Jakarta

Setiawan, Ade I. 1993. Pare dan Labu. Penebar Swadaya. Jakarta.

Sunaryono, H. 2003. Kunci Bercocok Tanam Sayur-Sayuran Penting Di Indonesia. Sinar Baru Algesindo. Bandung.

Suprapti, Lies. 2005. Awetan Kering dan Dodol Waluh. Kanisius. Yogyakarta.

Adiono, Hari Purnomo.1985. Ilmu Pangan. Universitas Indonesia Press. Jakarta

Rindiastuti,Yuyun.2008.http://yuyunrindi.files.wor dpress.com/2008/03/proposal1.pdf . Diakses pada tanggal 24 November 2008 pukul 18.00 WIB.

Tisnadjaja, Djadjat. 2006. Bebas Kolesterol dan Demam Berdarah dengan Angkak. Penebar Swadaya. Jakarta

Sofian, A. 1997. Zat Makanan dan Fungsinya. CV. Tangerang. Jakarta.

Winarno, F. G., 1997. Kimia Pangandan Gizi. PT. Gramedia PustakaUtama, Jakarta 